\title{
Inhibition of Hepatic Binding of Thyroxine by Cholecystographic Agents
}

\author{
James V. Felicetta, William L. Green, and Wil B. Nelp, Department of Medicine, \\ University of Washington School of Medicine, Seattle, Washington 98105
}

A B S T RAC T Subsequent to studies indicating that cholecystographic agents and sulfobromophthalein (BSP) inhibit uptake of thyroxine $\left(\mathrm{T}_{4}\right)$ by rat liver slices, the effect of such compounds on hepatic storage of $\mathrm{T}_{4}$ in man has been examined. After intravenous administration of $\left[{ }^{125} \mathrm{I}\right] \mathrm{T}_{4}$ to five normal subjects, hepatic radioactivity, estimated by external gamma counting, rose to a peak in $\sim 4 \mathrm{~h}$ and then declined in parallel with serum radioactivity. When a 6-g dose of the cholecystographic agent, tyropanoate (Bilopaque), was administered orally $3 \mathrm{~d}$ later, estimated hepatic extravascular radioactivity fell $50-60 \%$ within $4 \mathrm{~h}$ and then rose toward the pretyropanoate value. Concomitant with the fall in hepatic radioactivity, serum radioactivity rose $57-70 \%$, as did stable $\mathrm{T}_{4}$ levels in serum, suggesting that hormone discharged from the liver entered the serum. Both uptake of $\mathrm{T}_{4}$ and discharge by tyropanoate were much less in two patients with liver disease.

Ipodate (Oragrafin), 12 g orally in two subjects, caused much smaller changes in hepatic and serum radioactivity. However, ipodate also caused a doubling of the percent free $T_{4}$ in the serum as judged by equilibrium dialysis, and the ratio of hepatic radioactivity to free $\left[{ }^{125} \mathrm{I} \mathrm{T}_{4}\right.$ in serum declined markedly after ipodate, similar to the fall in hepatic:serum ${ }^{125} \mathrm{I}$ ratios after tyropanoate. BSP, $20 \mathrm{mg} / \mathrm{kg}$ i.v. in three subjects, caused a smaller change; the decline in hepatic $\mathrm{T}_{4}$ content averaged $19 \%$.

We conclude that these organic anions, tyropanoate, ipodate, and BSP, all can displace $\mathrm{T}_{4}$ from the liver. The results imply a link between $T_{4}$ transport and organic anion transport, and indicate a mechanism for altering hepatic $T_{4}$ content in man that could be the site of physiologic regulation or of disease. A method is described whereby analysis of the change in hepatic and plasma radioactivity after tyropanoate could be employed to estimate hepatic $\mathrm{T}_{4}$ content in diverse clinical circumstances.

This work was presented in part at the 61st Annual Meeting of the Endocrine Society, Anaheim, Calif., June 1979.

Received for publication 13 November 1979 and in revised form 7 January 1980.

\section{INTRODUCTION}

It was once thought that iodine-containing radiographic contrast agents affect thyroid function chiefly by releasing inorganic iodide. However, two drugs employed for oral cholecystography, iopanoate (Telepaque, Winthrop Laboratories, N. Y.) and ipodate (Oragrafin, E. R. Squibb \& Sons, Princeton, N. J.), are now known to cause a major decline in circulating levels of the potent thyroid hormone triiodothyronine $\left(\mathrm{T}_{3}\right)^{1}$ by virtue of their ability to inhibit peripheral conversion of thyroxine $\left(T_{4}\right)$ to $T_{3}(1,2)$. Cholecystographic agents also inhibit conversion of $T_{4}$ to $T_{3}$ in vitro (3-5).

Yet another effect of iopanoate and ipodate on thyroid hormone economy has recently been demonstrated in our laboratory, namely, their ability to inhibit uptake of $T_{4}$ and $T_{3}$ by rat liver slices; similar effects were produced by sulfobromophthalein (BSP) and bilirubin (4). The findings suggested that the agents might be able to discharge thyroid hormones from the liver in vivo. To study this possibility in man, we chose the agent sodium tyropanoate (Bilopaque, Winthrop Laboratories) because Suzuki et al., ${ }^{2}$ in comparing the effect of various agents on hormone levels, found that this drug provoked an acute and significant increase in serum $\mathrm{T}_{4}$. Our results indicate that a major discharge of $T_{4}$ from the liver follows tyropanoate ingestion; ipodate and BSP cause a similar but less striking discharge.

\section{METHODS}

Subjects. Five healthy volunteers were studied: three white men and two white women (Table I). All had normal

\footnotetext{
${ }^{1}$ Abbreviations used in this paper: BSP, sulfobromophthalein; ISF, interstitial fluid, RIA, radioimmunoassay; $T_{3}$, triiodothyronine; $\mathrm{T}_{4}$, thyroxine.

2 The following work was published after manuscript was written: Suzuki, H., N. Kadena, K. Takeushi, and S. Nakagawa. Effects of three-day oral cholecystography on serum iodothyronines and TSH concentrations: comparison of the effects among some cholecystographic agents and the effects of iopanoic acid on the pituitary-thyroid axis. Acta Endocrinol. 92: 477-488.
} 
TABLE I

Clinical Data of Subjects

\begin{tabular}{cccccccccc}
\hline Subject & Age & Sex & Height & Weight & T 4 RIA & $\mathrm{T}_{3}$ RIA & $\begin{array}{c}\mathrm{T}_{3} \text { resin } \\
\text { uptake }\end{array}$ & Thyrotropin & Comment \\
\hline & $y r$ & & $c m$ & $k g$ & $\mu g / d l$ & $n g / d l$ & $\%$ & $\mu U / m l$ & \\
1 & 43 & $\mathrm{M}$ & 183 & 68 & 6.0 & 106 & 42 & 6.0 & Recurrent pancreatitis \\
2 & 57 & $\mathrm{M}$ & 169 & 65 & 5.9 & 107 & 44 & 3.0 & Normal \\
3 & 27 & $\mathrm{M}$ & 166 & 59 & 9.5 & 104 & 37 & 3.2 & Normal \\
4 & 57 & $\mathrm{~F}$ & 152 & 62 & 6.8 & 102 & 40 & 1.9 & Hashimoto's thyroiditis* \\
5 & 55 & $\mathrm{~F}$ & 166 & 64 & 15.0 & 198 & 49 & 1.5 & Hashimoto's thyroiditis* \\
6 & 41 & $\mathrm{M}$ & 185 & 82 & 7.6 & 63 & 49 & 3.0 & Alcoholic hepatitis \\
7 & 58 & $\mathrm{M}$ & 175 & 68 & 3.4 & 50 & 63 & 3.5 & Viral hepatitis \\
Normal range & & & & $4.1-11.3$ & $70-200$ & $33-45$ & $<6.0$ & \\
\hline
\end{tabular}

* Both women were receiving $0.2 \mathrm{mg}$ levothyroxine daily.

liver function as evidenced by normal serum tests of liver function (bilirubin, alkaline phosphatase, glutamic-oxaloacetic transaminase) and normal values for BSP excretion. All were clinically euthyroid, and four had normal values for serum $\mathrm{T}_{4}$ by radioimmunoassay (RIA), $\mathrm{T}_{3}$ resin uptake, and thyrotropin. The two women had euthyroid goiter, clinically diagnosed as Hashimoto's thyroiditis and treated with $0.2 \mathrm{mg}$ levothyroxine daily; subject 5 had modestly elevated hormone levels. Two male in-patients with liver disease were also studied (Table I). During the period of study, serum bilirubin levels averaged $12.0 \mathrm{mg} / \mathrm{dl}$ in both subject 6 and 7 , and respective values were 141 and 31 U/liter (normal, <25 U/liter) for serum glutamic-oxaloacetic transaminase and 3.6 and $2.6 \mathrm{~g} / \mathrm{dl}$ for serum albumin. The study was approved by the Human Subjects Review and Radiation Safety Committees of the University of Washington; informed consent was obtained in writing from each subject.

Standard protocol. Each subject was first started on saturated solution of potassium iodide, 5 drops orally every $12 \mathrm{~h}$, to block thyroidal uptake of labeled iodide. After intravenous injection of $50 \mu \mathrm{Ci}$ of ${ }^{125} \mathrm{I}$-labeled $\mathrm{T}_{4}$ (Industrial Nuclear Co., St. Louis, Mo.), serial counts were made over the hepatic area, employing a shielded sodium iodide crystal detector. Additionally, serum samples were obtained at the same times as the liver counts, and counted together with standards prepared from the injection solution in a well-type scintillation detector (Beckman Gamma 4000, Beckman Instruments, Inc., Fullerton, Calif.). All counting was performed with a relative error of $<3 \%$.

After $\sim 72 \mathrm{~h}$, long enough for hepatic and serum counts to reach a steady state of decline, a 6-g dose of sodium tyropanoate was administered orally; liver counting and blood sampling continued for another $24-48 \mathrm{~h}$. The patient was fasting on the morning of drug administration to promote more rapid absorption of the gallbladder agent; the fast was ended $4 \mathrm{~h}$ after drug ingestion.

4-7 d after tyropanoate administration, when liver:serum ${ }^{125}$ I ratios had stabilized near their original level, three subjects were given BSP intravenously, $5 \mathrm{mg} / \mathrm{kg}$ on one day and $20 \mathrm{mg} / \mathrm{kg}$ on the following day. Serial liver counts and blood specimens were obtained as in the standard protocol.

Two volunteers were retested with ipodate. The protocol was identical except that the dose of ipodate was 12 rather than $6 \mathrm{~g}$. One subject was also retested using a 3-g and later a 9-g dose of tyropanoate.

External counting over the liver. Subjects were studied at two hospitals; at one the detector has a 2 -in. sodium iodide crystal and at the other a 3-in. crystal. Gamma energies from 20 to $65 \mathrm{keV}$ were counted and were corrected for room background. Using a point source of ${ }^{125} \mathrm{I}$ in a water bath, the half-thickness value for both probes was $0.75 \mathrm{~cm}$, i.e., the count rate decreased $50 \%$ for each $0.75-\mathrm{cm}$ distance in water from the crystal. Because of this limited range, heavy collimation to block out radioactivity from distant perihepatic tissues seemed unnecessary, and most subjects were studied without a collimator, applying the detector directly to the chest wall. The limited range did mean, however, that chest wall tissues could make a significant contribution to net count rates. Assuming a chest wall thickness of $2.5 \mathrm{~cm}$, and an "infinite" thickness of liver beyond, chest wall tissues would be counted at about eight times the efficiency of the liver and could contribute $10 \%$ to net counts even though the relative isotope concentrations in liver and chest wall were 50:1. Although the major conclusions of the present study are not compromised by this factor, a correction for chest wall activity would be necessary for precise quantitation of hepatic ${ }^{125}$ I content. The chest wall factor would be less, employing ${ }^{131}$ I-labeled hormones that have a more energetic gamma emission; $\left[{ }^{131} \mathrm{I}\right] \mathrm{T}_{4}$ was not readily available to us.

Special analyses on serum. Two additional procedures were used to determine the nature of the increased serum radioactivity produced by tyropanoate. First, a serum sample obtained from one subject at the peak of the tyropanoate effect was subjected to column chromatography on Sephadex G-25, using a technique previously described (6). Second, serum samples obtained from subject 5 just before tyropanoate and also at the peak of the tyropanoate effect were subjected to precipitation with trichloroacetic acid (TCA), using a modification of the technique of Lepp et al. (7). After initial counting, $0.125 \mathrm{ml}$ serum was mixed with $1.75 \mathrm{ml}$ distilled $\mathrm{H}_{2} \mathrm{O} ; 0.5 \mathrm{ml}$ of $40 \%$ TCA was then added. After mixing, the tube was centrifuged for $20 \mathrm{~min}$ at $2,000 \mathrm{rpm}$, the supernate decanted, and the tube recounted.

Serum samples from the ipodate studies were also subjected to equilibrium dialysis to determine the free $T_{4}$ fraction, using the technique of Sterling and Brenner (8). ${ }^{3}$

Analysis of data. Data analysis was similar to that of Cavalieri and Searle (9). $L(t)$ is the count rate over the liver at time (t) after $T_{4}$ injection, normalized to a value of 100 at $t=0$. Similarly, $S(t)$ is the count rate per unit volume of

${ }^{3}$ We are grateful to Dr. Margaret Kenny of the Department of Laboratory Medicine, University of Washington, for performing these determinations. 
serum or plasma, normalized to 100 at $t=0$. Count rates at $t=0$ were estimated by extrapolation of the early portions of the hepatic uptake and serum disappearance curves, respectively. It is assumed that $\mathrm{L}(0)$ is the result of radioactivity in the hepatic vascular space seen by the probe, and that the contribution of hepatic intravascular counts to total liver counts at any later time $t$ can be estimated as $L(0) \times S(t) / S(0)$, or, because $\mathrm{L}(0)$ and $S(0)$ are both normalized to 100 , simply as $S(t)$. Therefore, a ratio $L(t): S(t)>1.0$ implies entry of tracer into the hepatic extravascular space, and the difference, $\mathrm{L}(\mathrm{t})-\mathrm{S}(\mathrm{t})$, should be directly proportional to the hepatic extravascular radioactivity. Also, the percent change in hepatic extravascular $T_{4}$ content between any two times, $t_{1}$ and $t_{2}$, can be expressed as

$$
\Delta(\mathrm{L}-\mathrm{S})=\frac{\mathrm{L}\left(\mathrm{t}_{1}\right)-\mathrm{S}\left(\mathrm{t}_{1}\right)-\left(\mathrm{L}\left[\mathrm{t}_{2}\right]-\mathrm{S}\left[\mathrm{t}_{2}\right]\right)}{\mathrm{L}\left(\mathrm{t}_{1}\right)-\mathrm{S}\left(\mathrm{t}_{1}\right)} \times 100 .
$$

\section{RESULTS}

Effects of tyropanoate. Fig. 1 shows the results of the complete study in subject 3 . There was a rapid initial uptake of hormone by the liver, reaching a maximum $\sim 4 \mathrm{~h}$ after injection. Hepatic and serum ${ }^{125} \mathrm{I}$ then gradually declined over the next $72 \mathrm{~h}$, approximately in parallel. When tyropanoate was given, a prompt fall in hepatic radioactivity ensued, reaching a nadir $\sim 4 \mathrm{~h}$ later. There was a marked rise in the serum radioactivity at the same time that hepatic radioactivity fell, thus providing strong evidence that tyropanoate causes a discharge into the circulation of thyroxine stored within the liver. Over the next $48 \mathrm{~h}$, both liver and serum radioactivity returned toward values that would have been predicted had the drug not been administered, suggesting that the effect is reversible. This is consistent with tyropanoate's relatively brief biologic halflife, being rapidly excreted into bile and then removed in the feces (10).

The results in each of the five normal subjects were similar to those depicted in Fig. 1. As shown in Fig. 2, liver:serum ${ }^{125}$ I ratios rose to a plateau; individual plateau values varied from 10.4 to 15.5 , and half maximum ratios were reached in 1-2 h. After ad-

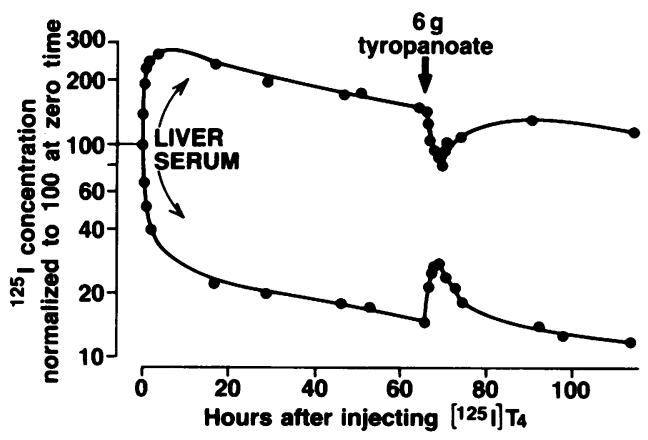

Figure 1 Effect of tyropanoate on labeled $\mathrm{T}_{4}$ in liver and serum. All ${ }^{125}$ I counts have been normalized to 100 at time of initial injection of labeled hormone.

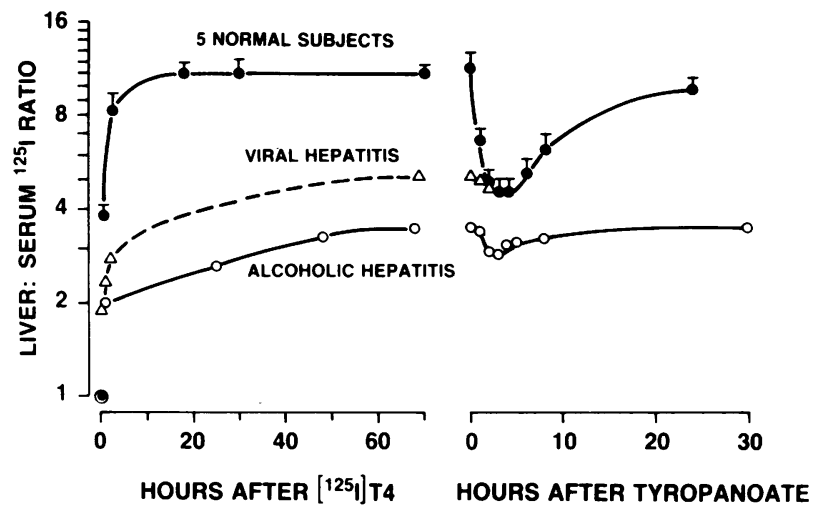

FIGURE 2 Effect of tyropanoate on hepatic $T_{4}$ content in normal subjects and in patients with liver disease. Liver:serum ${ }^{125} \mathrm{I}$ ratios, normalized to 1.0 at the time of $\left[{ }^{125} \mathrm{I}\right] \mathrm{T}_{4}$ injection, are shown for five normal subjects $(\Theta)$, one patient with alcoholic hepatitis $(O)$, and one with viral hepatitis $(\triangle)$.

ministration of tyropanoate, the ratio fell in $2-4 \mathrm{~h}$ to a nadir that varied from 2.8 to 5.3 .

Fig. 3 shows all five subjects plotted together, with the values for liver:serum ratios having been normalized to a value of 1.0 at the time of tyropanoate administration. Expressed in this manner, there was a remarkable uniformity in the pattern of decline in the liver:serum ratios. Also shown in this figure is the result in one subject who was retested with 3- and 9-g doses of tyropanoate; the change in liver:serum ratios was roughly proportional to dosage. In conjuction with the 9-g dose, serial counts were made over the left lower quadrant of the abdomen and over the right and left upper chest. In each site, concomitant with the rise in serum ${ }^{125}$ I content and the fall in count rate over the liver, tyropanoate administration was followed by a rise in the count rate.

In the serum sample obtained at the peak of the tyropanoate effect, and subjected to column chro-

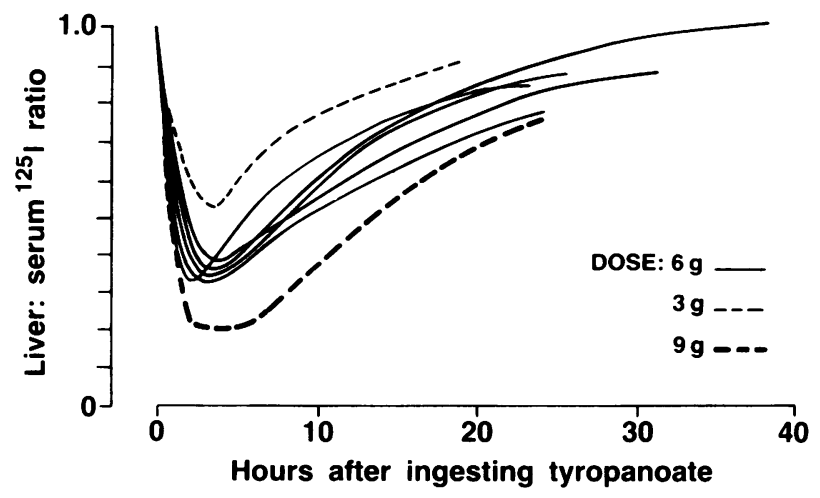

FIGURE 3 Effect of tyropanoate on hepatic $\left[{ }^{125} \mathrm{I}\right] \mathrm{T}_{4}$ content. The liver:serum ratio at the time of tyropanoate administration has been normalized to a value of 1.0. The results in one subject who was restudied with 3- and 9-g doses of tyropanoate are shown by the light and heavy dashed lines, respectively. 
matography, $90 \%$ of the radioactivity migrated in the expected location of $\mathrm{T}_{4}$. This is confirmation that the radioactivity discharged from the liver is $T_{4}$ rather than a metabolic breakdown product. The results obtained by TCA precipitation provide additional confirmation. In a control sample of serum, to which a known amount of [ $\left.{ }^{125} \mathrm{I}\right] \mathrm{T}_{4}$ had been added, $90 \%$ of the radioactivity was precipitated with TCA. In a serum sample drawn just before giving tyropanoate, the value was $92 \%$, and in two samples taken near the peak of tyropanoate's effect, the values were 89 and $93 \%$. This is evidence that breakdown of $\mathrm{T}_{4}$ to iodide is not a major part of the response to tyropanoate administration.

The pattern of change in hepatic extravascular radioactivity $(\Delta[\mathrm{L}-\mathrm{S}]$, defined in Methods) and in serum radioactivity in the five studies with $6 \mathrm{~g}$ tyropanoate is shown in Fig. 4. The proportionate change in serum radioactivity exceeded that in the liver, suggesting that the amount discharged was a smaller proportion of hepatic radioactivity than of serum radioactivity. Serum radioactivity also peaked first, suggesting that egress from serum to nonhepatic sites occurred and equalled the rate of ingress from liver $2-3 \mathrm{~h}$ after tyropanoate ingestion. If all the radioactivity leaving the liver enters the serum, the ratio between the changes in serum and hepatic radioactivity, at an early time point before significant ${ }^{125}$ I has left the serum for nonhepatic sites, should equal the ratio between the hepatic $T_{4}$ distribution volume and the plasma volume. Table II summarizes the data at the first time point for which complete data are available, $1 \mathrm{~h}$. The mean ratio was about 1.8 , suggesting an hepatic distribution volume 1.8 times the plasma volume. Possible errors in this computation are considered in the Discussion.

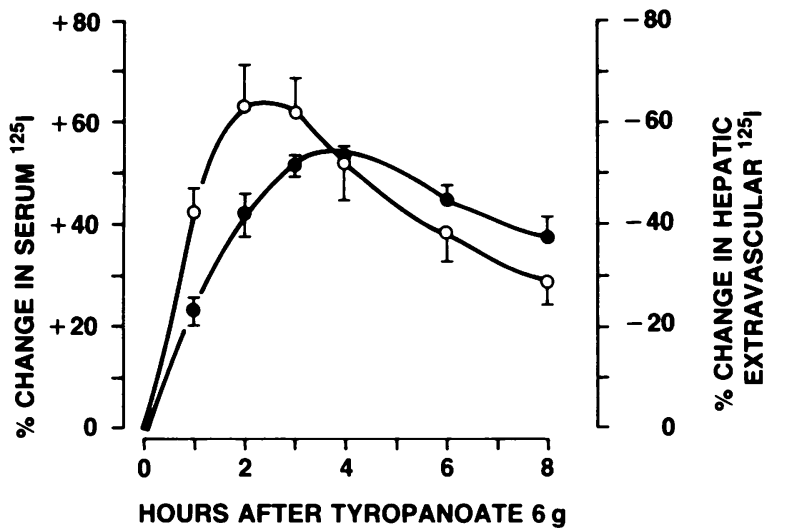

FIGURE 4 Changes in serum ${ }^{125} \mathrm{I}$ and in hepatic extravascular ${ }^{125}$ I after tyropanoate. Values for serum radioactivity $(O)$ are expressed as percent increase over the value at the time of tyropanoate ingestion. Hepatic extravascular radioactivity (O), estimated as described in Methods, is expressed as percent decrease from the value at the time of tyropanoate ingestion. Each symbol depicts mean and SE from five subjects.
TABLE II

Estimating the Ratio between Hepatic $T_{4}$ Distribution Volume and Plasma Volume

\begin{tabular}{ccccc}
\hline Subject & $\begin{array}{c}\text { Dose of } \\
\text { tyropanoate }\end{array}$ & $\Delta \mathrm{S}$ & $\Delta(\mathrm{L}-\mathrm{S})$ & $\Delta \mathrm{S} / \Delta(\mathrm{L}-\mathrm{S})^{*}$ \\
\hline & $g$ & \% in $1 \mathrm{~h}$ & \% in $1 h$ & \\
1 & 6 & 25.6 & 18.6 & 1.38 \\
2 & 6 & 44.7 & 25.1 & 1.78 \\
3 & 6 & 46.3 & 25.5 & 1.82 \\
4 & 6 & 37.1 & 15.1 & 2.46 \\
5 & 6 & 55.1 & 30.5 & 1.81 \\
Mean $\pm \mathrm{SE}$ & & $41.8 \pm 5.0$ & $23.0 \pm 2.7$ & $1.85 \pm 0.17$ \\
1 & 3 & 21.5 & 13.4 & 1.60 \\
1 & 9 & 67.0 & 36.7 & 1.83 \\
\hline
\end{tabular}

* As discussed in the text, this ratio should be a function of the ratio between hepatic $T_{4}$ distribution volume and plasma volume.

Computing the percent fall in hepatic extravascular radioactivity, $\Delta(\mathrm{L}-\mathrm{S})$, from the time of tyropanoate ingestion to the nadir, the mean value $\pm \mathrm{SE}$ was 55.3 \pm 2.0 (range, 52.2-60.7).

In selected serum samples, $\mathrm{T}_{4}$ RIA was measured to determine whether changes in serum radioactivity were accompanied by similar changes in serum-stable $\mathrm{T}_{4}$ concentrations. Compared with values just before tyropanoate ingestion, samples taken $2 \mathrm{~h}$ later, in three subjects, showed a mean percent increase in ${ }^{125} \mathrm{I}$ concentration, $\pm \mathrm{SD}$, of $68 \pm 8 \%$, although the mean increase in stable $\mathrm{T}_{4}$ was $67 \pm 15 \%$. At $8 \mathrm{~h}$ after tyropanoate, in four subjects, ${ }^{125} \mathrm{I}$ concentration was still $27 \pm 4 \%$, and stable $T_{4}$ concentration $31 \pm 8 \%$, above pretyropanoate values. These changes in stable $\mathrm{T}_{4}$ levels are comparable with those reported by Suzuki et al., ${ }^{2}$ who found a $25 \%$ increase in serum $\mathrm{T}_{4} 12 \mathrm{~h}$ after a 3-g dose of tyropanoate.

In the two patients with liver disease, hepatic $\mathrm{T}_{4}$ uptake, as judged by liver:serum ${ }^{125}$ I ratios, was much less than in the normal subjects (Fig. 2). Tyropanoate caused very little discharge from the liver of the patient with alcoholic hepatitis. Hepatic discharge was probably also minimal in the patient with viral hepatitis, although data are incomplete as the result of poor patient cooperation. These results indicate, as would be expected, that the storage pool affected by tyropanoate is markedly diminished in severe liver disease.

Effects of ipodate. Fig. 5 shows the effect of another cholecystographic agent, ipodate (Oragrafin), on labeled $\mathrm{T}_{4}$ in liver and serum in subject 2 ; similar results were obtained in subject 1 . Because of a report that ipodate may inhibit the binding of thyroxine to plasma proteins (11), the free $T_{4}$ fraction in each serum sample was determined by equilibrium dialysis, allowing estimation of the serum concentration of free 


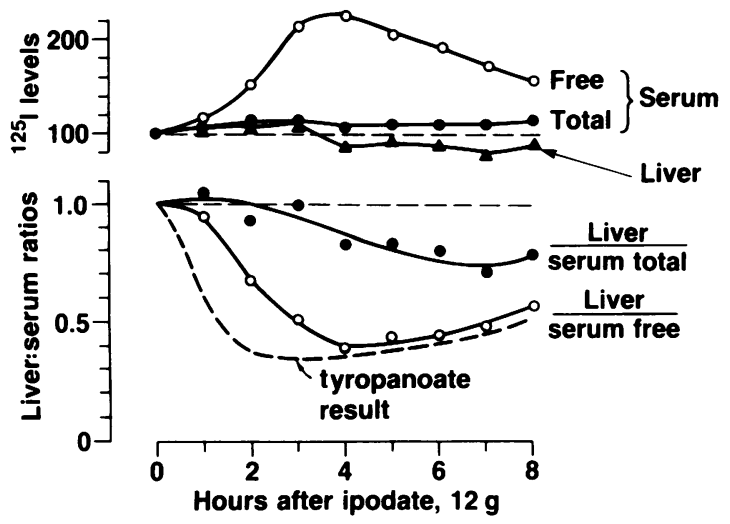

FIgURE 5 Effect of ipodate on hepatic $T_{4}$ content. All ${ }^{125} I$ levels have been normalized to a value of 100 at the time of ipodate administration. The top half of the figure depicts changes in the serum, both free and total, and in the liver. The bottom half of the figure depicts the ratios of liver to serum-total and of liver to serum-free counts.

labeled $\mathrm{T}_{4}$. During the 8-h period after the administration of a quadruple dose of ipodate, $12 \mathrm{~g}$, there were only small changes in total serum radioactivity and in the liver radioactivity, so that the ratio of hepatic to serumtotal radioactivity showed only a modest decline after ipodate. There was, however, a major rise in the free $\mathrm{T}_{4}$ counts, reaching a peak $4 \mathrm{~h}$ after administration of ipodate. Therefore, the ratio of hepatic to serum-free radioactivity underwent a major decline, with a temporal course reminiscent of the result with tyropanoate (Fig. 5). Thus, it appears that ipodate also can discharge $\mathrm{T}_{4}$ from binding sites in the liver, but this is obscured by its simultaneous effect of displacing the hormone from its binding sites on plasma proteins.

Effects of BSP. These experiments were performed to provide a further comparison with our findings in rat liver slices, where BSP was as effective as cholecystographic agents in inhibiting $\mathrm{T}_{4}$ uptake (4). With the small dose, $5 \mathrm{mg} / \mathrm{kg}$, any effect was smaller than the variability of the methods. The larger dose, $20 \mathrm{mg} / \mathrm{kg}$, caused a rise in serum radioactivity and a fall in hepatic radioactivity in all three subjects tested. The maximum changes in hepatic $\mathrm{T}_{4}$ content, by Eq. 1, were 26, 20, and $13 \%$ in the three subjects.

\section{DISCUSSION}

It is well known that the liver plays an important role in the distribution of thyroid hormones. Cavalieri and Searle (9) have speculated that the hepatic pool of $T_{4}$ acts as a buffer to modulate abrupt changes in the level of circulating hormone. Other workers have shown that alterations in the storage pool of thyroid hormone occur in a variety of pathophysiologic settings. Nicoloff and Dowling (12) and Busnardo et al. (13) have reported that hepatic accumulation of labeled $T_{4}$ is increased in subjects with hyperthyroidism and decreased in hypothyroid subjects. Patients with hepatic disease are known to have a reduction in hepatic $\mathrm{T}_{4}$ content $(9,12,14,15)$, presumably as the result of a decrease in the functioning mass of liver. In euthyroid subjects with normal liver function, the hepatic $\mathrm{T}_{4}$ distribution volume is a function of the percent free $T_{4}$ in plasma, and hence is decreased when levels of plasma $T_{4}$ binding globulin are increased by estrogen treatment (16). Conversely, the hepatic $\mathrm{T}_{4}$ distribution volume is increased when $T_{4}$ binding activity in plasma is decreased, as it is in patients with congenitally low levels of $\mathrm{T}_{4}$ binding globulin $(12,14,16,17)$, in subjects given androgens to lower $\mathrm{T}_{4}$ binding globulin levels (18), and in subjects given amounts of salicylates sufficient to displace $T_{4}$ from its binding proteins (19). Thus, the expected effect of a compound that increases percent free $T_{4}$, such as ipodate, would be to increase liver:serum $T_{4}$ ratios; its failure to do so in the present study suggests an additional effect of ipodate on hepatic $\mathrm{T}_{4}$ uptake.

Tyropanoate, ipodate, and BSP, the three compounds shown to discharge $T_{4}$ from liver in this study, are members of a larger group of organic anions taken up by the liver. Our results, therefore, imply a relationship between accumulation of thyroid hormones and of other organic anions by the liver. The findings also raise the possibility that other factors, both endogenous and exogenous, might alter hepatic hormone content and thus regulate the effects of thyroid hormones on hepatic function. Two possible mechanisms for the effects we have demonstrated can be considered: inhibition of binding to cytosol proteins and inhibition of transport through the plasma membrane.

Several groups of workers have identified specific proteins in the cytosol of liver cells that bind thyroid hormones, employing hepatic tissue from several species, including rat (20-22), dog (23), and man (24). Lichter et al. (25) have studied cytosol thyroid hormone binding proteins with particular emphasis on the organic anion binding proteins, $\mathrm{Y}$ (ligandin) and Z. In extensive earlier studies, these cytosol proteins were shown to bind bilirubin, BSP, and cholecystographic agents (26), and were found in all species tested, including rats, mice, guinea pigs, rhesus monkeys, sheep, and man. Lichter et al. (25) were able to show that both $T_{4}$ and $T_{3}$ are bound by both $Y$ and $Z$, and are displaced from these proteins by BSP and by bilirubin. However, there was prominent binding of the thyroid hormones to other cytosol proteins; the major portion of $\mathrm{T}_{4}$ was bound to a protein (or proteins) migrating near, but distinct from, albumin on Sephadex G-100. BSP and bilirubin displaced $\mathrm{T}_{4}$ from this protein as well as from $\mathrm{Y}$ and $\mathrm{Z}$. Dillman et al. (22) also described a rat liver cytosol protein that could bind $T_{4}$, and that had an affinity for BSP about 1:10,000 of that 
for $T_{4}$; the ratio of BSP to $T_{4}$ in the displacement studies by Lichter et al. (25) may have been in the same range. Although Davis et al. (23), in their study of canine liver cytosol proteins, did not see prominent binding of BSP to the cytosol $\mathrm{T}_{4}$-binding protein, they did not specifically study the ability of large amounts of BSP to displace $T_{4}$ from its specific protein.

Thus, the available evidence suggests that high concentrations of the organic anions, BSP and bilirubin, can displace $T_{4}$ from binding to cytosol proteins, even though the major protein involved may not be the $\mathrm{Y}$ or $\mathrm{Z}$ protein. Our own studies in liver slices (4) have shown that cholecystographic agents, including tyropanoate and ipodate, share with BSP and bilirubin the ability to displace $T_{4}$ from cells. The interaction of organic anions with hepatic $\mathrm{T}_{4}$ binding proteins may be weak in man, as it is in rats; the molar ratio between our standard dose of tyropanoate $(6 \mathrm{~g}, 9.0 \mathrm{mmol})$ and an estimate of hepatic $\mathrm{T}_{4}$ content $(270 \mu \mathrm{g}, 0.35 \mu \mathrm{mol})$ is in the neighborhood of 25,000:1. The effective dose of BSP, $20 \mathrm{mg} / \mathrm{kg}$, would represent $\sim 2 \mathrm{mmol}$, yielding a $\mathrm{BSP}: \mathrm{T}_{4}$ ratio of $6,000: 1$.

In addition to cytosol binding proteins, it is possible that plasma membrane transport plays a role in the accumulation of cholecystographic agents and $T_{4}$ by hepatocytes. Scharschmidt et al. (27) have demonstrated in the rat that there is a carrier-membrane transport system for the hepatic uptake of organic anions such as BSP, bilirubin, and indocyanine green. The agents are mutually competitive ligands for this process. Receptors for BSP have been identified in liver plasma membranes (28). Pliam and Goldfine (29) have demonstrated specific thyroid hormone binding sites in rat liver plasma membranes. It seems conceivable, therefore, that competitive inhibition of inward transport through the plasma membrane is another mechanism of tyropanoate's effects; to explain discharge of accumulated hormone by this mechanism would also require that exit from the cell be less inhibited than entry, and that exit be fairly rapid.

The two possible mechanisms have quite different implications for the intracellular fate of $T_{4}$. If cholecystographic agents interfere primarily with membrane transport, this could result in a lowering of intracellular free $T_{4}$ levels. On the other hand, if the primary effect is to inhibit binding of $\mathrm{T}_{4}$ already within the cell to cytosol proteins, cholecystographic agents should transiently increase the intracellular free $T_{4}$ levels. Further study is clearly indicated to sort through these possibilities and to determine the effect of gallbladder agents upon intracellular free $T_{4}$ levels.

Our data in patients with liver disease, although limited, suggest that the dischargeable hepatic $T_{4}$ pool was almost abolished. Also, there was a slower rate of initial equilibration between count rates over the liver and serum ${ }^{125}$ I concentration (Fig. 2); this may reflect uptake into chest wall tissues that accumulate $T_{4}$ at the slow rate characteristic of the arm $(30)$, leg $(9,17)$, or muscle tissue in general (31).

It has previously been shown that a major effect of cholecystographic agents is to block the peripheral conversion of $\mathrm{T}_{4}$ to $\mathrm{T}_{3}(1-5)$, an effect shared by tyropanoate. ${ }^{2}$ Indeed, Wu et al. (32) have used repeated doses of ipodate in the treatment of hyperthyroidism. A decreased hepatic uptake of $T_{4}$ is one potential mechanism for decreased $T_{3}$ formation; Jennings et al. (33) have recently suggested that decreased hepatic uptake of $\mathrm{T}_{4}$, rather than decreased activity of a converting enzyme, is responsible for the decreased rate of $T_{3}$ production that occurs in fasting. However, when the time-course we have demonstrated for tyropanoate's effect on hepatic $\mathrm{T}_{4}$ content (maximum at $4 \mathrm{~h}$, dissipated by $24 \mathrm{~h}$ ) is compared with that for inhibition of $\mathrm{T}_{3}$ formation (persisting beyond $3 \mathrm{~d}^{2}$ ), it seems likely that the two effects are separate.

There has been disagreement in the literature concerning the magnitude of the hepatic storage pool for thyroid hormones. Nicoloff and Dowling (30) calculated that the liver represents about $14 \%$ of the total nonthyroidal pool of $T_{4}$; a similar estimate was made by Busnardo et al. (13). Cavalieri and Searle, however, reported values twice as large for this pool, claiming that nearly one-third of the total nonthyroidal pool of $T_{4}$ is located in the liver $(9,17)$. The figure offered by Oppenheimer et al. (14) is in close agreement; they report that $29 \%$ of the total extrathyroidal pool is in the liver, and similar values are given by some other workers $(15,16)$.

Further support for the larger hepatic pool size derives from extensive studies performed both in sheep $(34,35)$ and in man $(36)$ by Irvine, who concludes that the liver contributes $30 \%$ of the total pool of extrathyroidal $\mathrm{T}_{4}$ in man (31). The smaller estimates derive from models in which the interstitial fluid (ISF) is viewed as a separately equilibrating compartment, whose size is estimated by the early passage of radioactivity into the arm (30) or thigh (13). Irvine has, however, demonstrated that the rate of change in the specific activity of lymph in animals injected with labeled hormone varies from organ to organ, so that the ISF specific activity in each organ is about the same as the total tissue specific activity (35), i.e., transfer of $\mathrm{T}_{4}$ from plasma to ISF is the rate-limiting step in tissue entry. This negates the assumption by Nicoloff and Dowling (12) of a distinct ISF pool; moreover, their assumption that the liver has an ISF compartment corresponding to the early change in arm:plasma count rate ratios results in assigning a large component of hepatic $T_{4}$ to the interstitial space. Evidence that the hepatic interstitial $T_{4}$ pool is small has been provided in autoradiographic studies by Oppenheimer et al. $(14,37)$ and in direct postmortem measurements of 
hepatic interstitial $\mathrm{T}_{4}$ in sheep where the ratio, hepatic ISF $\mathrm{T}_{4}$ : hepatic plasma $\mathrm{T}_{4}$, was $<0.2(34)$.

Expressing the data of Cavalieri and Searle $(9,17)$, Oppenheimer (14), and Irvine (31) as a ratio of hepatic $\mathrm{T}_{4}$ content to plasma $\mathrm{T}_{4}$ content $\left(\mathrm{T}_{4}\right.$ content $=$ volume $\times \mathrm{T}_{4}$ concentration), the individual values range from 0.97 to 1.85 with median values between 1.3 and 1.4 . Our average estimate, 1.8 (Table II), is higher. Because there were no evident errors in our estimation of plasma radioactivity, the major error that could elevate the ratio would be an underestimate of the proportion of radioactivity discharged from the liver $(\Delta[\mathrm{L}-\mathrm{S}]$ in Table II). It is possible that the segment of liver counted is not representative, and that portions of the liver distant from the probe discharge more completely; there is no noninvasive method to check this possibility, although gamma camera images of the liver, performed in subject 2 , showed a uniform loss of ${ }^{125}$ I after tyropanoate. A more well-defined source of error is the contribution of chest wall radioactivity to "liver" counts. In one subject, placing the probe over the upper chest gave a count rate about one-tenth that over the liver, before tyropanoate ingestion. Using this value to correct for the chest wall contribution in each subject, the mean value for $\Delta(\mathrm{L}-\mathrm{S})$ in Table II becomes $26 \%$, and the mean ratio falls to 1.67 . Finally, some of the ${ }^{125} \mathrm{I}$ entering serum may have come from tissues other than the liver. Discharge of $\mathrm{T}_{4}$ from the kidney by tyropanoate seems particularly likely because we have shown that cholecystographic agents inhibit $\mathrm{T}_{4}$ uptake by rat kidney slices; ${ }^{4}$ the kidney has transport systems (38) and cytosol binding proteins for cholecystographic agents (39) similar to those found in liver, and has been shown to concentrate $T_{4}$ in man (37). Assuming that the renal pool is one-sixth the size of the hepatic pool, this would further reduce the estimate of the liver space alone to 1.4 times the plasma volume, more closely agreeing with earlier workers. It does seem unlikely that other tissues are responsible for much of $T_{4}$ discharge. Counting over the upper chest, there was actually a rise in radioactivity after tyropanoate; in studies not reported here, we have observed similar increases in radioactivity over the arm and thigh after tyropanoate ingestion. In each site, the rise has been compatible with the rise in plasma radioactivity, and there was little net change in extravascular radioactivity in the chest wall, arm, or thigh. In other words, tyropanoate did not appear to cause significant discharge of $T_{4}$ from skeletal muscle, the major repository of extravascular $T_{4}$ beside liver and kidney (31).

There are other possible errors in our method that could lead to an underestimate of the hepatic $T_{4}$ space. First, tyropanoate could discharge ${ }^{125} \mathrm{I}$ into bile so that

${ }^{4}$ Green, W. L., and G. Bellamy. Unpublished observations. only a portion of $T_{4}$ lost from the liver entered serum. Also, from the nature of the curve in Fig. 6, it seems likely that some of the ${ }^{125} \mathrm{I}$ entering serum from liver had already been lost to other extravascular sites by $1 \mathrm{~h}$, and that ratios computed at earlier time intervals would have been higher and would more accurately reflect relative distribution volumes. It is of course possible that estimates in the literature are low. In particular, some of the values for plasma volume reported by Cavalieri and Searle $(9,17)$ and by Oppenheimer et al. (14) seem large.

The only agent previously shown to displace labeled $\mathrm{T}_{4}$ from the liver (40) with a concomitant rise in serum radioactivity $(40,41)$ is diethyl ether; a similar redistribution of $\mathrm{T}_{4}$ may be caused by halothane (42) and isoflurane (43). The published data concerning the effects of ether anesthesia on radioactivity in serum, liver, and thigh in subjects who had received $\left.{ }^{131} \mathrm{I}\right] \mathrm{T}_{4}$ $60 \mathrm{~h}$ earlier (40) can be interpreted as showing some discharge from the thigh as well as the liver, ${ }^{5}$ in contrast to tyropanoate which does not discharge $T_{4}$ from the thigh. We speculate, therefore, that the effect of ether has a different mechanism than the effect of tyropanoate, and, thus, that the present studies may be the first example in man of a direct effect on hepatic $\mathrm{T}_{4}$ content. Agents inhibiting hepatic storage of $\mathrm{T}_{4}$ may provide a useful tool for investigating the effects of disease and physiologic variables on hepatic storage. From considerations discussed above, our standard protocol provides an approximate estimate of the distribution volume ratio between liver and serum. This method could be applied, for example, to determine whether fasting alters hepatic storage of $\mathrm{T}_{4}$ in man, as it apparently does in rats (33).

\section{ACKNOWLEDGMENTS}

The authors are indebted to Susan Leatherman, Charlotte Hynes, and Muriel Elder for skilled assistance in preparing the manuscript.

This research was supported by U.S. Public Health Service grants AM 15810 and AM 07247, and a portion of the work

\footnotetext{
${ }^{5}$ Oyama et al. (40) reported a mean rise of $55 \%$ in serum $\left.{ }^{[131} \mathrm{I}\right] \mathrm{T}_{4}$ and no change in radioactivity in the thigh, after $40 \mathrm{~min}$ of ether anesthesia. If, as reported by Cavalieri (9), $30 \%$ of the thigh counts represent intravascular radioactivity, the failure of thigh counts to change when serum radioactivity rose implies some loss of extravascular radioactivity from the thigh; substituting thigh radioactivity for liver radioactivity in Eq. 1, and assuming that $30 \%$ of initial thigh radioactivity was intravascular, the data of Oyama et al. (40) indicate a $25 \%$ decline in thigh extravascular $T_{4}$ content during anesthesia. A firm conclusion cannot be reached, however, because ether may also cause changes in regional blood flow and in plasma volume. Using labeled human serum albumin, we have shown in two subjects that tyropanoate does not alter plasma volume, nor the amount of externally detected labeled albumin in liver and thigh.
} 
was conducted through the Clinical Research Center facility at the University of Washington, supported by National Institutes of Health grant RR-37.

\section{REFERENCES}

1. Bürgi, H., C. Wimpfheimer, A. Burger, W. Zaunbauer, H. Rösler, and T. Lemarchand-Beraud. 1976. Changes of circulating thyroxine, triiodothyronine and reverse triiodothyronine after radiographic contrast agents. J. Clin. Endocrinol. Metab. 43: 1203-1210.

2. Wu, S-Y., I. J. Chopra, D. H. Soloman, and L. R. Bennett. 1978. Changes in circulating iodothyronines in euthyroid and hyperthyroid subjects given ipodate (Oragrafin), an agent for oral cholecystography. J. Clin. Endocrinol. Metab. 46: 691-697.

3. Kaplan, M. M., and R. D. Utiger. 1978. Iodothyronine metabolism in rat liver homogenates. J. Clin. Invest. 61: 459-471.

4. Green, W. L., and G. Bellamy. 1977. Role of organic anion transport systems in uptake and metabolism of thyroid hormones by rat liver slices. Program of the 53rd Annual Meeting of the American Thyroid Association, Cleveland, Ohio. TR-16. (Abstr.).

5. Chopra, I. J. 1978. Inhibition of outer ring monodeiodination of $T_{4}$ and reverse $T_{3}\left(\mathrm{rT}_{3}\right)$ by some radiocontrast agents. Clin. Res. 26: 303A. (Abstr.).

6. Green, W. L. 1972. Separation of iodo compounds in serum by chromatography on Sephadex columns. J. Chromatogr. 72: 83-91.

7. Lepp, A., H. Pena, V. Hoxie, and L. Oliver. 1965. Proteinbound iodine determination with stable end point. Am.J. Clin. Pathol. 44: 331-341.

8. Sterling, K., and M. A. Brenner. 1966. Free thyroxine in human serum: simplified measurement with the aid of magnesium precipitation. J. Clin. Invest. 45: 153-163.

9. Cavalieri, R. R., and G. L. Searle. 1965. The role of the liver in the distribution of ${ }^{131} \mathrm{I}$ thyroxine in man. In Current Topics in Thyroid Research: Proceedings of the Fifth International Conference. C. Cassano and M. Andreoli, editors. Academic Press, Inc., New York. 336-345.

10. McChesney, E, W. 1971. Routes and rates of excretion of radiocontrast agents. In International Encyclopedia of Pharmacology and Therapeutics. Section 76. Radiocontrast Agents. P. K. Knoeffel, editor. Pergamon Press Ltd., Oxford. 1: 335-344.

11. Cristofori, F. C., and G. G. Duncan. 1964. Effect of a new orally administered cholecystographic compound on the $I^{131}$-triiodothyronine red-cell-uptake test of thyroid function. N. Engl. J. Med. 271: 564-565.

12. Nicoloff, J. T., and J. T. Dowling. 1968. Studies of peripheral thyroxine distribution in thyrotoxicosis and hypothyroidism. J. Clin. Invest. 47: 2000-2015.

13. Busnardo, B., M. E. Girelli, L. Varotto, and A. Giacobbi. 1974. Computer analysis of early thyroxine distribution in thyrotoxicosis and hypothyroidism. Horm. Metab. Res. 6: 202-207.

14. Oppenheimer, J. H., G. Bernstein, and J. Hasen. 1967. Estimation of rapidly exchangeable cellular thyroxine from the plasma disappearance curves of simultaneously administered thyroxine- ${ }^{131} \mathrm{I}$ and albumin- ${ }^{125} \mathrm{I}$. J. Clin. Invest. 46: 762-777.

15. Yumoto, Y., T. Namba, and H. Yamamoto. 1970. Kinetic analysis of thyroxine outside thyroid with ${ }^{131}$ I-thyroxine by aid of computer-with special reference to liver diseases. Acta Med. Okayama. 24: 457-470.

16. Musa, B. U., R. S. Kumar, and J. T. Dowling. 1969. Role of thyroxine-binding globulin in the early distribution of thyroxine and triiodothyronine. J. Clin. Endocrinol. Metab. 29: 667-674.

17. Cavalieri, R. R., and G. L. Searle. 1966. The kinetics of distribution between plasma and liver of ${ }^{131}$ I-labeled L-thyroxine in man: observations of subjects with normal and decreased serum thyroxine-binding globulin. J. Clin. Invest. 45: 939-949.

18. Zaninovich, A. A., R. Volpe, R. J. Soto, and C. Ezrin. 1969. Accumulation and release of thyroid hormones by the normal and diseased human liver. Acta Endocrinol. 60: $412-422$.

19. Musa, B. U., R. S. Kumar, and J. T. Dowling. 1968. Effects of salicylates on the distribution and early plasma disappearance of thyroxine in man. J. Clin. Endocrinol. Metab. 28: 1461-1464.

20. Hamada, S., K. Torizuka, T. Miyake, and M. Fukase. 1970. Specific binding proteins of thyroxine and triiodothyronine in liver soluble proteins. Biochim. Biophys. Acta. 201: 479-492.

21. Spaulding, S. W., and P. J. Davis. 1971. Thyroxine binding to soluble proteins in rat liver and its sex dependence. Biochim. Biophys. Acta. 229: 279-283.

22. Dillman, W., M. I. Surks, and J. H. Oppenheimer. 1974. Quantitative aspects of iodothyronine binding by cytosol proteins of rat liver and kidney. Endocrinology. 95: 492-498.

23. Davis, P. J., B. S. Handwerger, and F. Glaser. 1974. Physical properties of a dog liver and kidney cytosol protein that binds thyroid hormone. J. Biol. Chem. 219: 6208-6217.

24. Hamada, S., and M. Fukase. 1976. Demonstration and some properties of cytosol-binding proteins for thyroxine and triiodothyronine in human liver. J. Clin. Endocrinol. Metab. 42: 302-308.

25. Lichter, M., G. Fleischner, R. Kirsch, A. J. Levi, K. Kamisaka, and I. M. Arias. 1976. Ligandin and $\mathrm{Z}$ protein in binding of thyroid hormones by the liver. Am.J. Physiol. 230: $1113-1120$.

26. Levi, A. J., Z. Gatmaitin, and I. M. Arias. 1969. Two hepatic cytoplasmic protein fractions, $\mathrm{Y}$ and $\mathrm{Z}$, and their possible role in the hepatic uptake of bilirubin, sulfobromophthalein, and other anions. J. Clin. Invest. 48: 2156-2167.

27. Scharschmidt, B. F., J. G. Waggoner, and P. D. Berk. 1975. Hepatic organic anion uptake in the rat. J. Clin. Invest. 56: $1280-1292$.

28. Reichen, J., B. L. Blitzer, and P. D. Berk. 1977. The binding of organic anionic dyes to hepatocellular plasma membranes. Clin. Res. 25: 468A. (Abstr.).

29. Pliam, N. B., and I. D. Goldfine. 1977. High affinity thyroid hormone binding sites on purified rat liver plasma membranes. Biochem. Biophys. Res. Commun. 79: 166-172.

30. Nicoloff, J. T., and J. T. Dowling. 1968. Estimation of thyroxine distribution in man. J. Clin. Invest. 47: 26-37.

31. Irvine, C. H. G. 1975. Four compartment model of thyroxine metabolism. In Thyroid Hormone Metabolism. W. A. Harland and J. S. Orr, editors. Academic Press, Inc., New York. 163-188.

32. Wu, S-Y., I. J. Chopra, D. H. Solomon, and D. E. Johnson. 1978. The effect of repeated administration of ipodate (Oragrafin) in hyperthyroidism. J. Clin. Endocrinol. Metab. 47: 1358-1362.

33. Jennings, A. S., D. C. Ferguson, and R. D. Utiger. 1979. Regulation of the conversion of thyroxine to triiodothyronine in the perfused rat liver. J. Clin. Invest. 64: $1614-1623$.

34. Irvine, C. H. G. 1974. Concentration of thyroxine in cellular and extracellular tissues of the sheep and the 
rate of equilibration of labeled thyroxine. Endocrinology. 94: 1060-1071.

35. Irvine, C. H. G., and M. W. Simpson-Morgan. 1974. Relative rates of transcapillary movement of free thyroxine, protein-bound thyroxine, thyroxine-binding proteins, and albumin. J. Clin. Invest. 54: 156-164.

36. Irvine, C. H. G. 1968. Effect of exercise on thyroxine degradation in athletes and non-athletes. J. Clin. Endocrinol. Metab. 28: 942-948.

37. Oppenheimer, J. H., M. I. Surks, and H. L. Schwartz. 1969. The metabolic significance of exchangeable cellular thyroxine. Recent Prog. Horm. Res. 25: 381-414.

38. Bárány, E. H. 1973. The liver-like anion transport system in rabbit kidney, uvea and choroid plexus. II. Efficiency of acidic drugs and other anions as inhibitors. Acta Physiol. Scand. 88: 491-504.
39. Kirsch, R., G. Fleischner, K. Kamisaka, and I. M. Arias. 1975. Structural and functional studies of ligandin, a major renal organic anion-binding protein. J. Clin. Invest. 55: 1009-1019.

40. Oyama, T., S. Shibata, and A. Matsuki. 1969. Thyroxine distribution during ether and thiopental anesthesia in man. Anesth. Analg. 48: 1-6.

41. Fore, W., P. Kohler, and J. Wynn. 1966. Rapid redistribution of serum thyroxine during ether anesthesia. J. Clin. Endocrinol. Metab. 26: 821-830.

42. Oyama, T., S. Shibata, S. Matsuki, and T. Kodo. 1969. Thyroxine distribution during halothane anesthesia in man. Anesth. Analg. 48: 715-719.

43. Oyama, T., P. Latto, D. A. Holaday, and H. Chang. 1975. Effect of isoflurane anaesthesia and surgery on thyroid function in man. Can. Anaesth. Soc. J. 22: 474-477. 